\title{
Modes of Oceanic and Atmospheric Circulation During the Quaternary
}

\author{
S. RAHMSTORF ${ }^{1}$ and F. SIROCKO ${ }^{2}$ \\ ${ }^{1}$ Potsdam Institute for Climate Impact Research (PIK), 14412 Potsdam, Germany \\ ${ }^{2}$ Institute of Geoscience, University of Mainz, 55099 Mainz, Germany
}

\begin{abstract}
Paleoclimatic evidence shows that the ocean and atmosphere have undergone major changes during the Quaternary. For atmospheric mean circulation, data are consistent with changes in strength and shifts in position of major atmospheric circulation features (e.g., the westerly wind belt), whereas the structure of these main features appears to have persisted. For the ocean, evidence points to qualitative reorganizations in the thermohaline circulation. Modes of ocean-atmosphere variability, such as El Niño-Southern Oscillation (ENSO) and North Atlantic Oscillation (NAO), also appear to have changed or even been absent at times.
\end{abstract}

\section{INTRODUCTION}

In this chapter, we discuss the modes of operation of the oceanic and atmospheric circulation during the Quaternary. We begin by briefly highlighting key features of the oceanic and atmospheric circulation of the present-day Earth. Then we explore the range of possibilities for different behaviors of the planetary circulation system, as suggested by models, and review paleoclimatic evidence on the types of circulation that actually occurred during the Quaternary. We focus on dynamic changes in the ocean and atmosphere and less on the direct thermodynamic response of surface temperature to radiative forcings (Milankovich, $\mathrm{CO}_{2}$, etc.), although we do not completely ignore the latter.

Is the current state of the thermohaline ocean circulation, with deep water forming in the North Atlantic and around Antarctica, unique? Was the current three-cell (Hadley, Ferrel, and polar cells) structure of the atmospheric meridional circulation maintained in the Quaternary? Did the dominant ocean-atmosphere variability modes (ENSO and NAO) persist throughout this period? Answers to these questions will yield important clues as to what dynamic 
changes in ocean-atmosphere behavior might be expected during the Anthropocene.

\section{THE PRESENT STRUCTURE OF OCEANIC AND ATMOSPHERIC CIRCULATIONS}

Atmospheric and oceanic circulations are turbulent, complex flows with variability on all spatial and time scales. Despite this, some first-order, large-scale structures of the mean flow can be described, as can a few dominant coherent variability modes. These main structures and modes are our primary focus in this chapter.

Mean atmospheric circulation is organized in three main meridional cells in each hemisphere: (a) the Hadley cell, which extends across the tropics and subtropics, (b) the Ferrel cell in midlatitudes, and (c) the polar cell in high latitudes (Figure 8.1). This circulation is a response to solar heating in the tropics (causing rising air) and net radiative cooling in high latitudes. The most simple circulation driven by such heating and cooling would be one cell rising in the tropics and sinking near the poles, with warm air flowing aloft towards the pole and cold air flowing along the surface towards the equator. The Earth's rotation, however, does not permit such a simple flow since the Coriolis term dominates the equations and vorticity conservation inhibits north-south flow. As a result, air rising in the tropics descends in the subtropics, and the near-surface, equatorward winds of this Hadley cell take on a strong easterly component (i.e., the easterly trade winds). The seasonal cycle further modifies the circulation by causing a rising motion in the summer hemisphere and sinking in the winter hemisphere

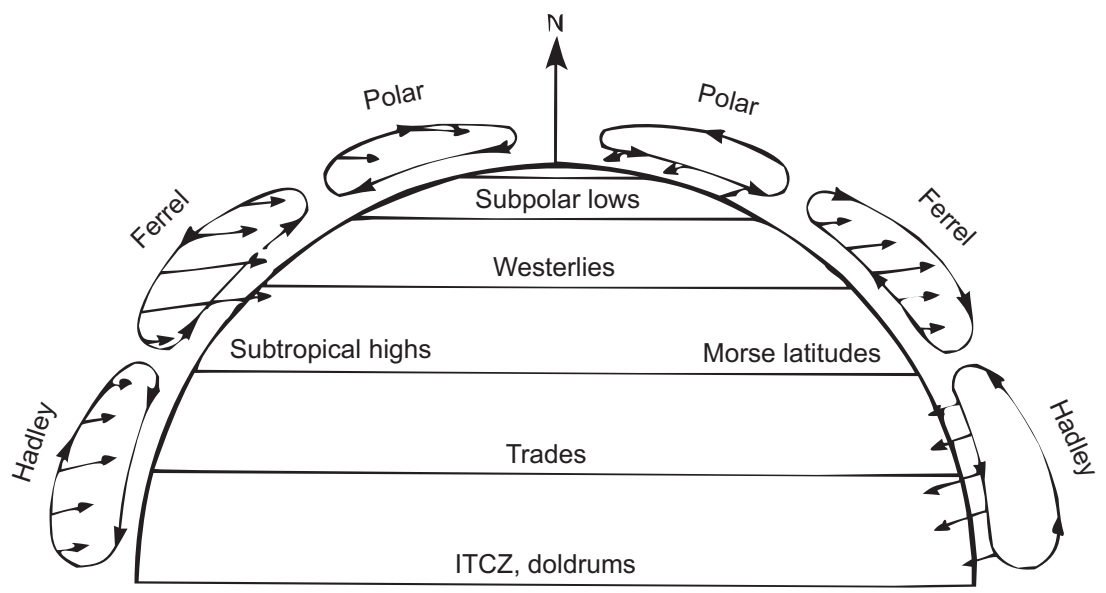

Figure 8.1 Basic structure of atmospheric circulation, showing the tropical Hadley cells, midlatitude Ferrel cells, and polar cells. Upper- and lower-level winds have directions suggested by the top and bottom arrows attached to the cells. From Apel (1987). 
(i.e., one cross-hemispheric Hadley cell); only in the annual mean does the nearly symmetric picture, with one Hadley cell in each hemisphere, appear. As a result, the intertropical convergence zone (ITCZ) shifts north and south across the equator with the seasons. In midlatitudes, the near-surface winds, driven by the north-south pressure gradient, form the westerly wind belt. This westerly flow is dynamically unstable, forming synoptic eddies (cyclones and anticyclones) that contribute much to the meridional transport of heat and moisture in the atmosphere.

Wind-driven ocean circulation is predominantly organized in basin-scale horizontal gyres (i.e., subtropical and subpolar gyres) and is driven by the vorticity input from the prevailing surface winds (trade winds, westerly belt). As a consequence of the vorticity balance on a rotating sphere, flow on the western side of these gyres is concentrated in swift western boundary currents (e.g., the Gulf Stream in the North Atlantic, the Kuroshio in the North Pacific); the return flow, however, is more diffuse. These gyre circulations occupy the upper portion (several hundred meters) of the oceans.

By contrast, thermohaline ocean circulation covers the full depth range of the ocean. It is driven by heat and freshwater fluxes at the ocean surface and subsequent interior mixing of heat and salt. It can be described as a global-scale overturning of water masses, with sinking (i.e., deepwater formation) in a few locations balanced by a broader upwelling motion. There are deepwater masses from two main sources: (a) North Atlantic deep water (NADW), presently formed mainly in the Greenland-Norwegian and Labrador seas, and (b) Antarctic bottom water (AABW), presently formed primarily in the Weddell and Ross seas. The compensating upward motion in the ocean is not as localized and cannot be measured; tracer and modeling studies(Toggweiler and Samuels 1993) suggest that much of it may occur in the Southern Ocean aided by the wind (Ekman divergence).

Variability in the ocean-atmosphere system is not just random, uncorrelated noise but is partly organized in coherent large-scale variability modes with characteristic timescales, as can be shown by empirical orthogonal function analysis of global weather observations. The two leading variability modes on short timescales (decades or shorter) are ENSO and NAO or northern annular mode.

Below, we explore how stable and persistent these structures of the mean circulation and variability modes were in the Quaternary as well as what we know about the first-order changes in planetary circulation during this period.

\section{THE LAST GLACIAL MAXIMUM}

A good starting point for discussion is the Last Glacial Maximum (LGM), 20 thousand years (Ka) before present (BP). Quaternary climate is characterized by oscillations of global climate between two extreme states: cold glacials with large continental ice cover (covering much of North America and Eurasia) and 
interglacials with minimal ice cover (confined primarily to Antarctica and Greenland) (Figure 8.2). At least during the past four glacial cycles $(420 \mathrm{Ka})$, both the cold and warm limits of these oscillations appear to be remarkably constant, with similar values in global ice volume, atmospheric $\mathrm{CO}_{2}$, and other parameters being reached every cycle. The present Holocene interglacial thus represents a warm extreme of the Quaternary climate range, whereas LGM represents the most recent cold extreme. There is a wealth of proxy data and model simulations about LGM climate which, taken together, allow many inferences about past ocean and atmosphere circulation.

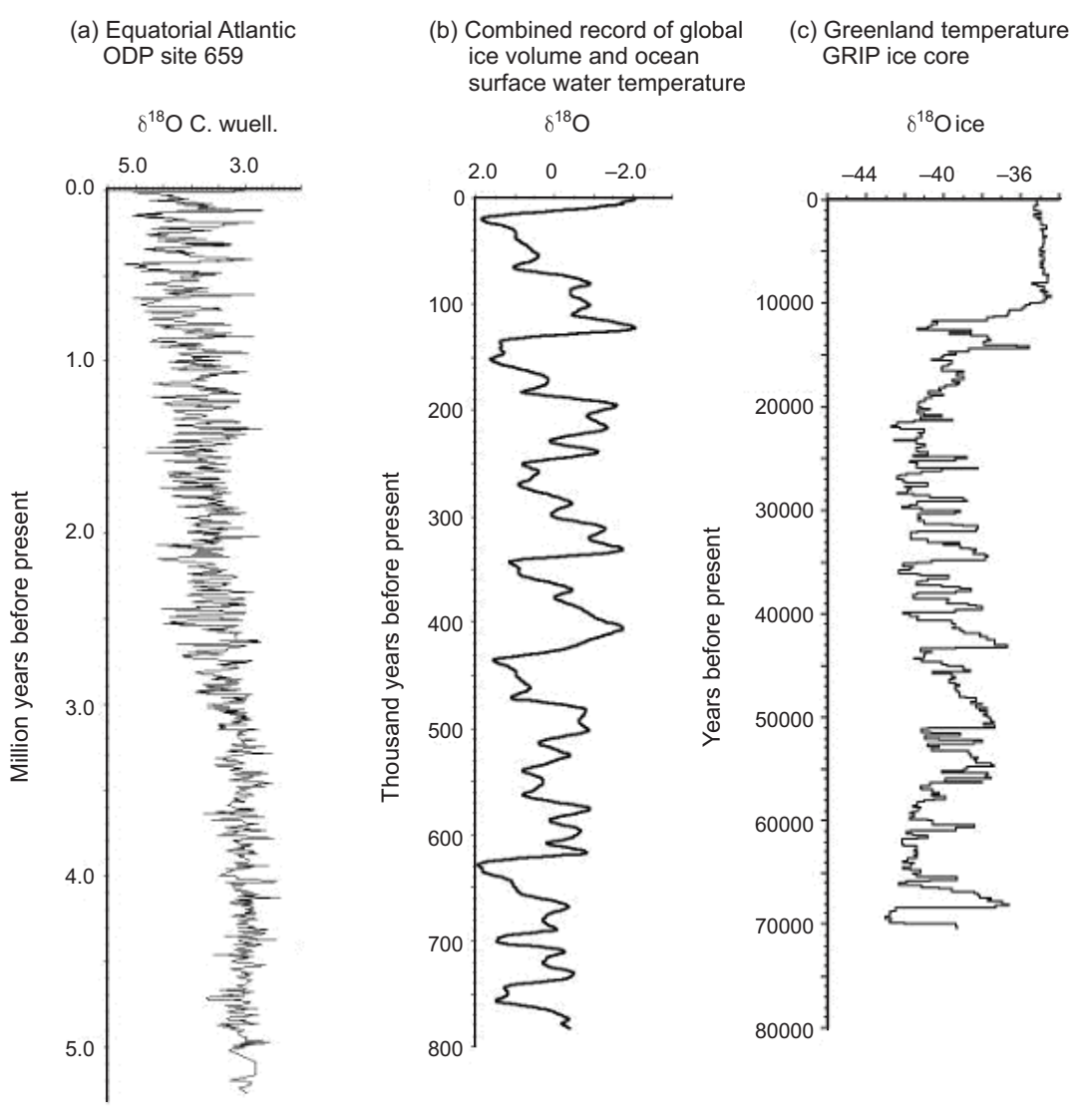

Figure 8.2 Timescales and time series of climate change during the Quaternary. (a) Oxygen isotope $\delta^{18} \mathrm{O}$ composition of benthic foraminifera in a deep-sea core (ODP site 659) from the equatorial west Atlantic (Tiedemann et al. 1984). (b) The SPECMAP $\delta^{18} \mathrm{O}$ stack of planktonic foraminifera from various deep-sea cores (Martinson et al. 1987). (c) Air temperature-related $\delta^{18} \mathrm{O}$ record of the Greenland ice core GRIP (Johnsen et al. 1992). 
Since the pioneering work of Milankovich, insolation has been regarded as the primary forcing of the ice ages during the Quaternary. The climatic evolution during the past 2.5 million years shows clear cyclicities of about 19,000, 23,000, 41,000 , and 100,000 years. These are attributable to rhythmic variations in the orbital constellation of the Earth to the Sun and are clearly seen in various paleoclimate records. According to the orbital theory of climate evolution, ice ages are triggered by insolation minima. Nevertheless, the LGM occurred during a time when the insolation patterns were almost identical to the present day, since the LGM occurred exactly one precessional cycle (of 20,000 years) ago. However, the Earth was very different in those days.

Proxy data from continental and marine geoarchives suggest a number of differences in the glacial atmospheric circulation compared to the present. The most obvious difference was the presence of ice sheets that were 3- to 4-km thick in northern Eurasia and North America, extending southward to about $52^{\circ}-45^{\circ} \mathrm{N}$ (CLIMAP). The ice sheets must have acted as topographic barriers for the west wind zone, contributing to its southward shift.

Much of the North Atlantic was covered with sea ice, and tundra vegetation dominated northern America and Europe. Cold desert dust storms were frequent in all of northern Europe, Asia, and North America along a corridor several hundred kilometers south of the continental ice sheets. The Sahara expanded and the tropical belt of rain forests in Africa and southern America shrank under reduced precipitation. Summer monsoon winds in southern Asia vanished completely (Sirocko et al. 1996). The mean annual temperature of the globe was about $4^{\circ}-8^{\circ} \mathrm{C}$ lower than at present; however, large regional variations occurred. Stute et al. (1995) measured a $5^{\circ} \mathrm{C}$ reduction of annual temperature from the noble gas composition of glacial groundwater aquifers in Brazil. Unfortunately, it is quite difficult to measure annual temperatures for the high latitudes because the seasonal temperature contrast must have been quite large near the ice-sheet margins.

This glacial world did not apparently result from insolation at the time (which was similar to the present) rather from its history, that is, from the amassment of ice sheets that began to form much earlier. Ocean records reveal a sharp sea-level drop at 118-115 Ka, which marked the end of the last interglacial $(128-118 \mathrm{Ka})$. Thereafter, within a few thousand years, sea level dropped by about $50 \mathrm{~m}$, or about $40 \%$ of the entire glacial-interglacial value (Figure 8.3). Modeling results indicate that the North American ice sheet formed during this time, and that it was characterized by extremely low summer insolation over the Northern Hemisphere. Positive feedbacks since this glacial inception (near 117 $\mathrm{Ka}$ ) caused the ice sheets to grow and cover much of northern Europe, at least during stage 4 (the first major cooling phase of the last glaciation).

The major feedback mechanisms were the role of ice-sheet topography and albedo, atmospheric carbon dioxide and water vapor concentrations, ocean circulation, sea-level changes associated with the waxing and waning of ice sheets, 


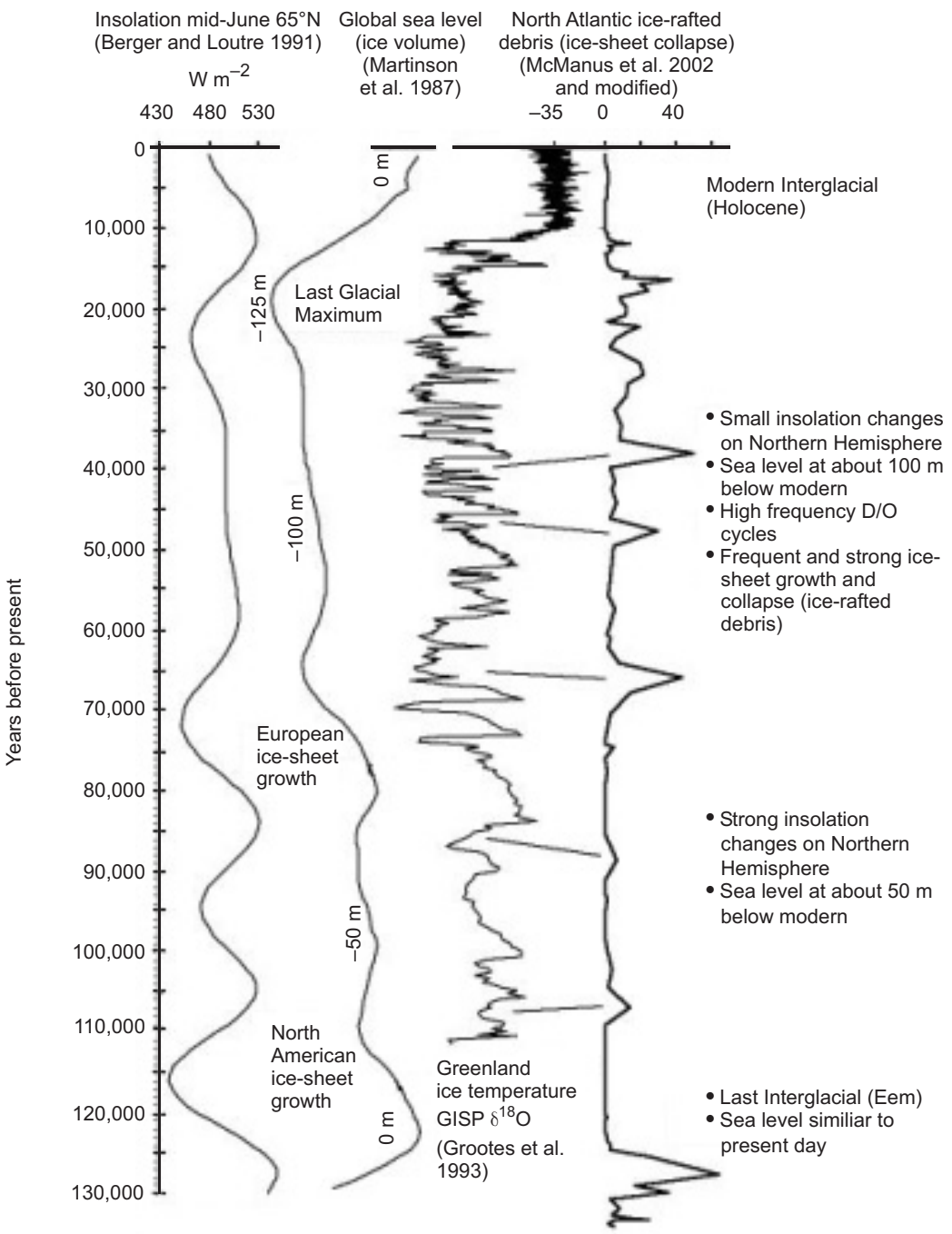

Figure 8.3 Insolation and sea-level change during the last 130,000 years in comparison to the structure of the Dansgaard/Oeschger (D/O) events (Greenland temperature) and surge of ice sheets during the Heinrich events, as recorded in North Atlantic deep-sea sediments by layers rich in drop stones from melting ice bergs (ice-rafted debris maxima). For the latest version of global sea level, see Siddall et al. (2003).

as well as the continental albedo and vegetation. Each of these parameters was powerful enough to affect climate and environment on a large, even global scale.

Despite these large changes in surface climate, the limited evidence available is consistent with changes in strength of key circulation features (trade winds, monsoon circulation) and some shifts in latitude (e.g., ITCZ and the northern westerly belt). There is, however, no evidence to suggest that the basic structure 
of the atmospheric circulation (as described above) changed in a qualitative way. For example, coral data from the Huon peninsula, taken from different portions of the Quaternary, show consistently a similar seasonal cycle (Tudhope et al. 2001), which under the present-day climate results from the seasonal passing of the ITCZ over this site. Apparently, this was a robust feature in the Quaternary. Proxy data for wet or dry conditions from a number of tropical South American sites suggest that the rainfall belt (i.e., the ITCZ) may have been further to the south in glacial times.

Turning now to ocean circulation, our discussion becomes more complex. Both quantitative and qualitative changes in ocean circulation have been discussed in the literature. Among the quantitative changes is a possibly enhanced subtropical gyre in the North Atlantic, which would be an expected result of stronger trade winds and westerlies. Oceanic evidence for an enhanced gyre is a regional warming in the Gulf Stream region.

For thermohaline circulation, earlier publications suggest that the LGM climate may be characterized by a complete absence of NADW formation. However, more recent evidence (Yu et al. 1996) suggests that NADW did form at a similar rate to that observed at present, though further south (to the south of Iceland) and reaching only lesser depths ( $1-2 \mathrm{~km}$, as compared to $2-3 \mathrm{~km}$ in modern climate).

The second major deep water mass, AABW, was also present in glacial times. Proxy data suggest (Labeyrie et al. 1992) a larger volume of water masses of Antarctic origin in the Atlantic compared to the present. However, this does not necessarily mean an enhanced formation rate of AABW, as it could simply reflect a change in relative densities of northern and southern source waters.

Thus, our current understanding suggests that, just as in the atmosphere, the basic structure of ocean circulation resembled that of the present climate, with some adjustments in flow rates and in the latitude of northern deepwater formation. However, unlike during the Holocene (with the possible exception of the 8.2-K event), this basic circulation pattern appears to have been unstable and to have undergone a number of major changes during transient millennial events.

\section{MILLENNIAL VARIABILITY DURING THE GLACIAL}

The ice ages not only experienced generally colder climates than at present, they were also punctuated by abrupt climatic transitions. The best evidence for these transitions, known as Dansgaard/Oeschger (D/O) events, comes from the last glacial. $\mathrm{D} / \mathrm{O}$ events typically start with an abrupt warming of around $10^{\circ} \mathrm{C}$ within a few decades or less, followed by gradual cooling over several hundred or thousand years. The cooling phase often ends with an abrupt final temperature drop back to cold ("stadial") conditions. Although they were first observed in the Greenland ice cores, D/O events are not a local feature of Greenland climate. Similar records have been found, for example, near Santa Barbara, 
California, in the Cariaco basin off Venezuela, and off the coast of India (for a compilation of evidence from 180 sites and references, see Voelker et al. 2002). $\mathrm{D} / \mathrm{O}$ climate change is centered on the North Atlantic and regions with strong atmospheric response to changes in the North Atlantic, with a weak response in the Southern Ocean or Antarctica.

The "waiting time" between successive $\mathrm{D} / \mathrm{O}$ events is most often around 1500 years or, with decreasing probability, 3000 or 4500 years (Alley et al. 2001). This suggests the existence of an as yet unexplained 1470-yr cycle that often (but not always) triggers a D/O event. This cycle has maintained its periodicity to within a few percent throughout at least the second half of the glacial (Rahmstorf 2003).

The second major type of climatic event in glacial times is the Heinrich event (Andrews 1998). Apparently, the large Eurasian and North American ice sheets surged every few thousand years and transported icebergs and ice-rafted debris (Figure 8.3) into the Atlantic (McManus et al. 2002). The nonlinear dynamics of ice sheets provide one plausible trigger mechanism. Ice sheets may grow for many thousands of years until their base melts due to trapped geothermal heat. Surges and strong calving result from a positive feedback: once the ice sheet moves, frictional heating causes further basal melting. This is an instability mechanism inherent to the continental ice sheets (see Payne, this volume).

The relationship of Heinrich events to sea-level change is not yet understood because we lack high-resolution sea-level reconstructions for the time of the ice-sheet decay. Records from the South Atlantic and parts of Antarctica show that the cold Heinrich events in the North Atlantic were associated with unusual warming there (Blunier et al. 1998), a fact sometimes referred to as "bipolar seesaw." A recent study from the Red Sea indicates that sea-level changes of up to $35 \mathrm{~m}$ may have occurred during times of the Antarctic warming (Siddall et al. 2003), that is, Heinrich layers likely occurred during a rise of global sea level by a few tens of meters. Initial sea-level rise, as a result of ice-sheet instability, could trigger further ice sheets by destabilizing the ice shelves at the margins of the continental ice.

Several climate models now incorporate continental ice sheets, and such models can reproduce irregular ice sheet surges. However, the interactions of the ice sheet with shelf ice and the ocean are currently only included in regional and process models, not yet in global climate models. Hence these models do not yet contain the mechanism for triggering and/or synchronizing ice-sheet surges via sea-level changes.

At the end of the last glacial, a particularly interesting abrupt climatic change took place, the so-called Younger Dryas event (12.8-11.5 Ka BP). Conditions had already warmed to near-interglacial conditions and continental ice sheets were retreating when, within decades, the climate in the North Atlantic region switched back to glacial conditions for more than a thousand years. It has been argued that the cooling resulted from a sudden influx of fresh water into the 
North Atlantic through the St. Lawrence River, when an ice barrier holding back a huge meltwater lake on the North American continent broke (Fairbanks 1989). This could have shut down NADW formation. Alternatively, the Younger Dryas may simply have been the last cold stadial period of the glacial following a temporary $\mathrm{D} / \mathrm{O}$ warming event (the Allerød event, the timing of which follows the 1500 -yr pattern of previous D/O events), and ended by another D/O warming (1,500 years after the Allerød). In fact, both views may be correct, with the Allerød (and perhaps the Bølling 1,500 yr earlier) causing the meltwater influx.

For the D/O, Heinrich, and Younger Dryas events, the paleoclimatic data clearly point to a crucial role of Atlantic Ocean circulation changes. Modeling and analytical studies of the Atlantic thermohaline circulation show that there are two positive feedback mechanisms leading to threshold behavior. The first, called advective feedback, is caused by the large-scale northward transport of salt by the Atlantic currents, which in turn strengthens the circulation by increasing density in the northern latitudes. The second, called convective feedback, is caused by the fact that oceanic convection creates conditions favorable for further convection. These (interconnected) feedbacks make convection and large-scale thermohaline circulation self-sustaining within certain limits, with well-defined thresholds where the circulation changes to a qualitatively different mode.

Three main circulation modes have been identified both in sediment data and models (Figure 8.4): (a) a warm or interglacial mode with deep water forming in the Nordic seas and large oceanic heat transport to northern high latitudes, (b) a cold or stadial mode with deep water forming south of the shallow sill between Greenland, Iceland, and Scotland and with greatly reduced heat transport to high latitudes, and (c) a "switched off" or "Heinrich" mode with practically no deepwater formation in the North Atlantic (Sarnthein et al. 1994). In the last mode, the Atlantic deep circulation is dominated by inflow of AABW from the south.

Many features of abrupt glacial climate can be explained by switches between these three circulation modes. Model simulations suggest that the cold stadial mode is the only stable mode in a glacial climate; it prevails during the cold stadial periods of the last glacial. D/O events can be interpreted as temporary incursions of warm Atlantic waters into the Nordic seas and deepwater formation there, that is, a switch to the warm mode causing abrupt climatic warming in the North Atlantic region (Ganopolski and Rahmstorf2001). As this mode is not stable in glacial conditions, the circulation starts to weaken gradually, and temperatures start to decline again immediately after the incursion until the threshold is reached where convection in the Nordic seas stops and the system reverts to the stable stadial mode. Heinrich events can be interpreted as a switch from the stadial mode to the Heinrich mode, that is, a shutdown of NADW. As this mode is probably also unstable in glacial conditions, the system spontaneously reverts to the stadial or warm mode after a waiting time of centuries, the timescale being determined partly by slow oceanic mixing processes. 

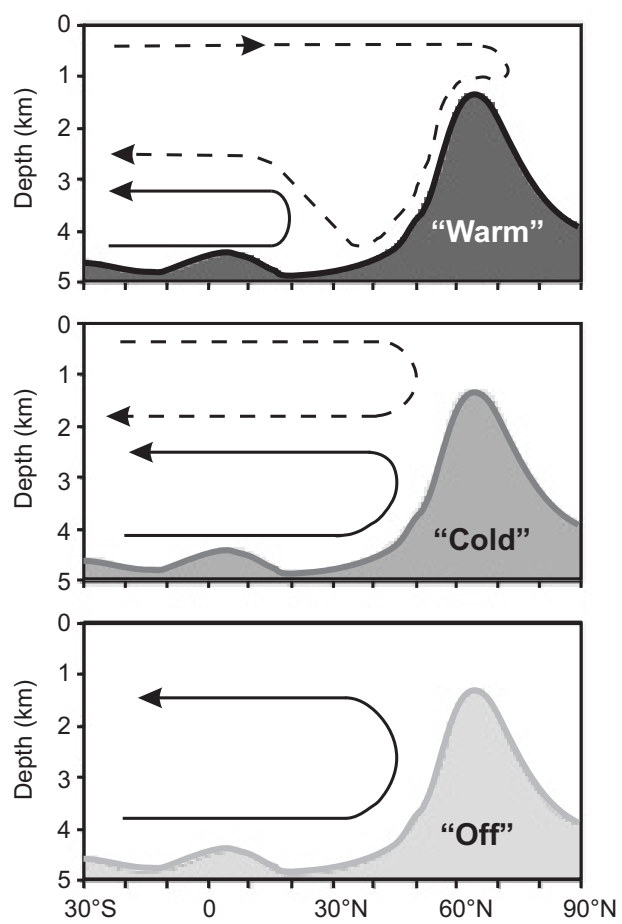

Figure 8.4 Three modes of ocean circulation that prevailed during different times of the last glacial period. A section along the Atlantic is depicted; the rise in bottom topography symbolizes the shallow sill between Greenland and Scotland. North Atlantic overturning is shown dashed, Antarctic bottom water solid. After Rahmstorf (2002).

This interpretation is consistent with the observed patterns of surface temperature change. Warming during D/O events is centered on the North Atlantic because this is where the change in oceanic heat transport occurs: the warm mode delivers heat to much higher latitudes than the cold mode. A switch to the Heinrich mode, on the other hand, strongly reduces the interhemispheric heat transport from the South Atlantic to the North Atlantic. This cools the Northern Hemisphere while warming the Southern Hemisphere, and explains the "bipolar seesaw" response in climate. It should be noted that the initial transient response can differ from the equilibrium response as the oceanic heat storage capacity is large. The patterns of these abrupt changes differ from the longer timescale (many thousands of years) response to the Milankovich cycles because for the latter the slow changes in atmospheric greenhouse gases (e.g., $\mathrm{CO}_{2}$ ) and continental ice cover act to synchronize and amplify climatic change globally.

Although threshold behavior of the Atlantic can dramatically shape and amplify climatic change, the question remains: What triggers the mode switches? As mentioned above, D/O switches appear to be paced by an underlying 
1,470 -yr cyclicity that has as yet to be explained. This could result from an external (astronomical or solar) cycle or an internal oscillation of the climate system. However, the extreme regularity of the underlying 1,470-yr cycle strongly argues for an origin outside the Earth system (Rahmstorf 2003). That each cycle does not necessarily trigger a $\mathrm{D} / \mathrm{O}$ event is probably the result of the presence of stochastic variability in the climate system as well as the presence of longer-term trends, such as the slow buildup of large continental ice sheets.

By contrast, ocean circulation change during Heinrich events can be explained by the amounts of fresh water entering the North Atlantic during these times in the form of icebergs. Simulations show that observed amounts of fresh water are sufficient to shut down deepwater formation in the North Atlantic.

\section{SHORT-TERM VARIABILITY MODES}

In present-day climate, ENSO is the strongest mode of natural climate variability. It is a coupled ocean-atmosphere mode that is centered on the tropical Pacific, with a variable period of 3-7 years, and it causes worldwide ecological and societal impacts due to its effect on the global atmospheric circulation. It is thus natural to ask whether this mode has also been in operation during different climatic states in the past. Annually banded corals provide a unique opportunity here, since they record climatic information at up to monthly rates of resolution based on the chemistry of their skeletons as they grow. As a result of tectonic uplift, fossil coral reefs from past climatic periods can be found on exposed terraces at some sites, such as the Huon peninsula of Papua, New Guinea.

Coral data from different time segments show convincingly that ENSO variability also prevailed under very different climates, including glacial times and the Eemian interglacial (Tudhope et al. 2001). The amplitude appears to have varied, however, with particularly weak ENSO variations during the mid-Holocene ( $6.5 \mathrm{Ka} \mathrm{BP})$ and the early glacial (112 Ka BP), and the strongest ENSO during modern times. First attempts to simulate the effect of Milankovich cycles on ENSO variations using a simple model suggest that the precession cycle could directly alter ENSO intensity by zonal asymmetric heating of the equatorial $\mathrm{Pa}$ cific (Clement et al. 2000). This data shows, however, that this cannot be the only effect. Thus, more data and further simulations with more comprehensive models are needed to understand ENSO variations through time.

Less information is available on the past operation of the NAO. Appenzeller et al. (1998) have attempted to reconstruct NAO variability from a west Greenland ice core, a location where a correlation with the NAO index is found for the observational period. This reconstruction goes back 350 years and reveals that NAO variability is intermittent, that is, not always clearly present. However, based on such a single time series, it is impossible to distinguish conclusively a spatially coherent mode such as the NAO from ordinary uncorrelated stochastic variability. 


\section{CONCLUSIONS}

The Quaternary underwent major climate changes, within consistent bounds, as a result of the insolation variations caused by the Milankovich cycles. The response of the Earth system to this forcing is obviously highly nonlinear, since a simple linear relation of, for example, ice volume proxies and Milankovich forcing does not exist. Much of the cause of this nonlinearity probably resides in the slow and nonlinear response of continental ice sheets to forcing (see Payne, this volume). Another part of this nonlinearity, however, resides in the response of atmosphere and ocean.

We have argued that the basic structure of the atmospheric circulation was probably not altered, although this is perhaps based more on the absence of evidence rather than on evidence for an absence of such a change. The limited paleoclimatic data for changes in atmospheric circulation is consistent with some quantitative changes and spatial shifts of key atmospheric circulation features, such as the westerlies or monsoons, but does not indicate, for example, qualitative reorganizations of the meridional circulation cells of the atmosphere. What might come closest to a qualitative change is the possibility of a shift in the location of tropical atmospheric convection, although evidence for this is thus far inconclusive. Such a shift could be important in that it could lead to large-amplitude global climate changes. It is intriguing to note that such a shift involves similar physics as in the case of the ocean: in both cases, the nonlinearity of the convection process is the deeper reason behind the large and nonlinear changes.

For ocean circulation, increasingly convincing evidence points to qualitative reorganizations of the thermohaline overturning circulation, and these have occurred repeatedly during the Quaternary. Some of these changes appear to have been in response to strong outside forcing, that is, a shutdown of NADW formation in response to ice-sheet surges (Heinrich events). For others (D/O events), no strong forcing mechanism is known. Data merely point to the timing being ruled by a 1,470-yr cycle of unknown origin, and simulations suggest that the ocean could have been close to a threshold where weak forcing was sufficient to trigger major circulation changes.

Concerning the major coherent short-term (decadal or shorter) variability patterns of the ocean-atmosphere system, ENSO, and NAO, the sketchy evidence available suggests that they may have operated only intermittently in the past. These patterns may thus be quite sensitive to forcing changes.

Which conclusions can be drawn for future anthropogenic climate change? Generally, the history of Quaternary climate suggests that the climate system is rather sensitive to forcing and responds in nonlinear ways, including the potential for strong amplifiers. Ocean circulation has responded with major changes in the past, not always due to strong forcing; thus the risk of future circulation changes must be taken seriously. Atmospheric variability patterns, like ENSO and NAO, may also have changed in the past and could be affected by future anthropogenic warming. Such nonlinear changes in the operation of ocean and 
atmosphere could have large and adverse impacts on human society. Although much progress has been made in modeling these mechanisms, it is difficult to predict the response of, for example, ENSO or the thermohaline circulation to anthropogenic increase in $\mathrm{CO}_{2}$. Therefore, the possibility of nonlinear responses in ocean and atmosphere adds uncertainty to our assessment of future climate changes and is a cause for caution.

\section{REFERENCES}

Alley, R.B., S. Anandakrishnan, and P. Jung. 2001. Stochastic resonance in the North Atlantic. Paleoceanography 16:90-198.

Andrews, J.T. 1998. Abrupt changes (Heinrich events) in late Quaternary North Atlantic marine environments: A history and review of data and concepts. J. Quat. Sci. 13: $3-16$.

Apel, J.R. 1987. Principles of Ocean Physics. London: Academic.

Appenzeller, C., T.F. Stocker, and M. Anklin. 1998. North Atlantic Oscillation in Greenland ice cores. Science 282:46-449.

Berger, A., and M.F. Loutre. 1991. Insolation values for the climate of the last 10 million years. Quat. Sci. Rev. 10:97-317.

Blunier, T., J. Chappellaz, J. Schwander et al. 1998. Asynchrony of Antarctic and Greenland climate change during the last glacial period. Nature 394:39-743.

Clement, A., R. Seager, and M.A. Cane. 2000. Suppression of El Niño during the mid-Holocene by changes in the Earth's orbit. Paleoceanography 15:731-737.

Fairbanks, R.G. 1989. A 17,000-year glacio-eustatic sea level record: Influence of glacial melting rates on the Younger Dryas event and deep-ocean circulation. Nature 342:637-642.

Ganopolski, A., and S. Rahmstorf. 2001. Rapid changes of glacial climate simulated in a coupled climate model. Nature 409:153-158.

Labeyrie, L.D., J.C. Duplessy, J. Duprat et al. 1992. Changes in the vertical structure of the North Atlantic ocean between glacial and modern times. Quat. Sci. Rev. 11: 401-413.

Johnsen, S.J., H.B. Clausen, W. Dansgaard et al. 1992. Irregular glacial interstadials recorded in a new Greenland ice core. Nature 359:311-313.

Martinson, D.G., N.G. Pisias, J.D. Hays et al. 1987. Age dating and the orbital theory of the ice ages: Development of a high resolution 0 to 300,000-year chronostratigraphy. Quat. Res. 27:1-29.

McManus, J.F., D.W. Oppo, L.D. Keigwin, J.L. Cullen, and G.C. Bond. 2002. Thermohaline circulation and prolonged interglacial warmth in the North Atlantic. Quat. Res. 58:17-21.

Rahmstorf, S. 2002. Ocean circulation and climate during the past 120,000 years. Nature 419:207-214.

Rahmstorf, S. 2003. Timing of abrupt climate change: A precise clock. Geophys. Res. Lett. 30:1510.

Sarnthein, M., K. Winn, S.J.A. Jung et al. 1994. Changes in east Atlantic deepwater circulation over the last 30,000 years: Eight time slice reconstructions. Paleoceanography 9:209-267.

Siddall, M., E.J. Rohling, A. Almogi-Labin et al. 2003. Sea level fluctuations during the last glacial cycle. Nature 423:853-858. 
Sirocko, F., D. Garbe-Schönberg, A. McIntyre, and B. Molfino. 1996. Teleconnections between the subtropical monsoon and high latitude climates during the last deglaciation. Science 272:526-529.

Stute, M., M. Forster, H. Frischkorn et al. 1995. Cooling of tropical Brazil $\left(5^{\circ} \mathrm{C}\right)$ during the last glacial maximum. Science 269:379-383.

Tiedemann, R., M. Sarnthein, and N.J. Shackleton. 1994. Astronomic timescale for the Pliocene Atlantic $\delta^{18} \mathrm{O}$ and dust flux records of Ocean Drilling Program site 659. Paleoceanography 9:619-638.

Toggweiler, J.R., and B. Samuels. 1993. New radiocarbon constraints on the upwelling of abyssal water to the ocean's surface. In: The Global Carbon Cycle, ed. M. Heimann, pp. 333-366. Berlin: Springer.

Tudhope, A.W., C.P. Chilcott, M.T. McCulloch et al. 2001. Variability in the El Niño-Southern Oscillation through a glacial-interglacial cycle. Science 291: 1511-1517.

Voelker, A.H.L et al. 2002. Global distribution of centennial-scale records for marine isotope stage (MIS) 3: A database. Quat. Sci. Rev. 21:1185-1214.

Yu, E.-F., R. Francois, and M.P. Bacon. 1996. Similar rates of modern and last-glacial ocean thermohaline circulation inferred from radiochemical data. Nature 379: 689-694. 